\title{
CLOSE ENCOUNTERS OF THE FOREIGN KIND: ALIENS AND OTHERS*
}

\author{
James R Cochrane \\ University of Natal \\ Pietermaritzburg
}

\begin{abstract}
'So then you are no longer strangers and aliens, but you are citizens with the saints and also members of the household of God.' Ephesians 2:19 ${ }^{1}$
\end{abstract}

\begin{abstract}
'The economic and social threat of the invading foreigner, from north of our borders in particular (legal and illegal immigrants), gives rise to xenophobic language and reactions, some violent. The grammar of alienating otherness is also present inside South Africa, most obviously in the discourses of unregenerate white South Africans who continue to conceive of blacks as ontologically, culturally or developmentally inferior. Strong feelings of local identity also create boundaries against others. All of this threatens an open society. Here I focus on the hermeneutics of alienated otherness, accepting that there are material conditions which shape it. I develop a position on alienated otherness by considering the particular case of xenophobia, through a reading of demon possession in the New Testament, via a critique of patriotism as nationalism, and by drawing on Ricoeur's. notion of the self as another and of tragic wisdom (ethical ambiguities and their effects). I conclude that we would be well advised to consider the 'aliens' in our midst in terms of overcoming practices and structures which produce alienated otherness, for wherever we allow the opposite, no matter in how minor a degree, we breed the conditions for the rupture of the body politic itself.'
\end{abstract}

\section{I}

The new 'Kafir' is on the horizon. This alienating term (originally meaning 'infidel' or 'non-Muslim' in Arabic) was, of course, applied pejoratively to black South Africans-to 'Bantu' in the language of apartheid. This kind of label, with its debasing parallel practices on the side of the labeller, is slowly being forced out of the core social body, of the lives of South Africans. But once more it seems to be re-entering our discourse, in concealed fashion, from another direction-in some of our views on the invading foreigner from north of our borders in particular.

The term 'kafir' itself may not be used for 'foreigners' who come to work and live in South Africa, but the economic and social threat such immigrants (legal and illegal) pose in the minds of ordinary people is all too often producing analogous language and the kind of actions one might expect ${ }^{2}$.

1 Because it is not irrelevant to the overall thrust of this essay, I note that this same text heads a recent publication by Paul Germond and Steve de Gruchy (eds.) on Aliens in the Household of God: Homosexuality and Christian Faith in South Africa, Cape Town: David Philip, 1997.

2 That this is not just a matter of discourse but of practice too, may be seen in the recent physical attack (12 August 1997) of informal sector entrepreneurs in Johannesburg on other foreign Africans who are deemed to be taking away their livelihood. 
Indeed, the grammar of alienating otherness is present not only between South Africans and others, but within the internal formations of South African society as well. Publicly, this is most obvious in the discourses of unregenerate white South Africans who cannot bring themselves to conceive of blacks (from whatever quarter) as anything but lower forms of human beings, whether ontologically or developmentally ${ }^{3}$.

Not so public are strong feelings of local identity, expressed as boundaries others should not cross which are felt to be threatened by any kind of open society. Frequently one hears of people who are not local being treated as alien - even if they speak the same language and carry the same racial burden bestowed upon them by apartheid and colonialism ${ }^{4}$ should they attempt to make any claims within the local context other than those granted by the rituals of hosting.

One might thus talk of a spectrum of alienated otherness. One could analyse this spectrum in terms of the material conditions or social location of the actors involved. But examining the material conditions or social location of any one person or group, though useful, is insufficient to uncover the specific point on that spectrum which they occupy in the minds of others, or for that matter, the point on the spectrum at which they would place another. A hermeneutic analysis is also necessary, for the reason that texts ${ }^{5}$ and actions which might tell us about discourses and practices of alienated otherness are neither transparent nor unambiguous ${ }^{6}$. An interpretative investigation would probe the codes, polysemic meanings and unexpressed absences in discourses and actions which a critical social analysis on its own cannot provide?

Aliens, then, do not in the first place come from outer space. They are our neighbourswhen we do not want them and when we are prepared to act against them to meet our interests. We are immediately familiar with prejudice against and fear of the other in our lives and it may well be that this direct context of caution and distancing is our first sense of an encounter with an unknown other.

I would then suggest that such encounters may lead to alienation of the another kind, namely, from ourselves. But this can only be so when the self is understood as constructed in relation to the other whose distancing then implies not only a loss of the other in some degree, but to a proportional degree, also the loss of the self. We would then say with Paul Ricoeur, and with the now almost clichéd African notion of ubuntu, that without the other there is no self. Julia Kristeva captures the nature of this relationship perfectly when she

3 The 'hidden transcript' of rugby coach André Markgraaff in his outburst about 'kaffirs' messing up South African rugby as whites understood it-made public in an unexpected way-is an indicator of how far this can go even among those who are now embarrassed by its exposure.

4 I have in mind, for example, the experience of two Friends, one of Zulu origin and the other of Sotho origin. who have found themselves working as pastors in another African language context among local people. Not only do they find no acceptance into the local patterns of culture, but they are treated at important moments as excluded foreigners by their own parishioners. This is not an uncommon experience between Afrikaner and English-speaking whites either.

5 'Texts' here implies more than the written word to include other forms of communication inscribed through rituals, songs, chants, visions, sermons, etc.

6 The notion that actions, like texts, are open to hermeneutic analysis comes from Paul Ricoeur. See his From Text to Action Essays in Hermeneutics II, Evanston: Northwestern University Press, 1991.

7 I take it for granted, incidentally, that depth hermeneutics investigates not only the world of language, but also the worlds of discourse which proscribe Language, including-vide Habermas-the (ink in discourse between system imperatives of money and power, and lifeworld imperatives, as well as the colonisation of the lifeworld by system imperatives. 
notes that, 'Strangely, the foreigner lives within us: he is the hidden face of our identity the space that wrecks our abode, the time in which understanding and affinity founder.'

If this understanding holds water, then 'the other,' for both anthropological and ontological reasons, must take priority over the self, or at least be given equal priority ${ }^{1}$. This, of course, is to reverse the order of priority with which contemporary global philosophies operate wherever the Cartesian ego, clothed in the garb of the instrumental rational individual of the market place or dressed in the theatrical costumes of the privatised id and libido, takes over. Here the isolated, atomised subject reigns supreme; here the other becomes either an extension of the one subject (my self becomes the universal self or an object beyond my self-solidified, whose otherness is turned into a thing

When this happens, George McLean notes, persons are construed 'as single entities wrapped in self-interests. ' Where this is the dominant ideology, external relations are likely to be constructed along utilitarian lines, and public order will be conceived in terms of 'merely instrumental relations assured by legal judgements rendered by the courts.' The long-term effect of such a logic is to exclude the ethical from the public arena and to relegate it to the private realm. It is to take integrating views of the meaning of life out of the public sphere.

In this context, it is necessary, McLean suggests ${ }^{1}$, to assert a different approach, one in which 'the transcendent and active principle of unity, solidarity and co-operation between persons and communities' provides the glue to bind increasingly different groups. The challenge is precisely to interpret what this means 'at the border of these felt unities where other persons or groups appear as markedly 'other,' alien, and threatening.'

We should be clear that this task is not one of deriving some abstract universal norms to which all should assent. Rather, it is that task of negotiating concrete norms on the basis of actual experience, embodied history and new possibilities together. The interest of hermeneutics in the fusion of horizons which are made up of distant traditions comes to the fore here, as does the interest of feminist theorists in asserting the importance of space, place and body in understanding both the conditions of suffering and the terms for its healing. We should keep these points in mind as we move into the next stage of reflection on aliens and others.

\section{II}

In order now to thread our way into the complex weave of issues which underlie the hermeneutics of alienated otherness, I wish to pursue the vexed question of foreign migrants and immigrants into South Africa. Let me concretise the question first. A brief description of the goals and rationale of The South African Migration Project (SAMP) provides us with an insight into some of the parameters that frame the question.

8 Julia Kristeva, Strangers to Ourselves, London Harvester Wheatsheat; 1991, p 1, in an aptly named chapter titled 'Toccata and Fugue for the Foreigner.'

9 Perhaps the reported formulation by Jesus of Nazareth of the Great Commandment suggests exactly this kind of anthropology and ontology Love God and your neighbour as your self.

10 George F. McLean, 'Philosophy and Civil Society: Its Nature, Its Past and Its Future,' in Civil Society and Social Reconstruction, ed. George McLean, Washington DC: Council for Research in Values and Philosophy, 1997 , p. 26.

11 Ibid., P. 21. 
Cross-border population migration in the South African Development Community $(\mathrm{SADC})^{\prime}$ poses multiple serious challenges to the region's governments. The way in which it is controlled will play a significant role in whether or not these movements undermine reconstruction and development in the region or contribute to it. The SAMP view, based on a preliminary multi-national fact finding mission, is that 'types, patterns, causes, consequences and impacts of the various forms of migration [in the SADC] are complex and variable and large knowledge gaps currently exist.' Dealing with the issue, the SAMP believes, is of major importance for 'social stability, regional integration, balanced development and sound policy.' It also notes that the economic implications of cross border migration for both source and host regions or states, including the benefits or costs of economic activity and remittance practice among migrants, is 'shrouded in disinformation."

In this context, the SAMP refuses to speak of 'illegal' immigrants, using the term 'undocumented migrants' instead. The hermeneutic shift in the language is important. It suggests that legal discourse is an insufficient basis either for understanding the problem or for resolving it. Of course, foreign migrant and immigration policy must necessarily find a legal framework and effective instruments by which the law may be applied. The SAMP deals with this too, and makes suggestions that lie somewhere between completely open borders and 'fortress South Africa.' But my focus here is on the notion that migrants are 'undocumented' rather than 'illegal,' as it serves to move our attention away from particular laws which may be in place, to the basis of law-making, that is, to the philosophical ethical foundations which should determine the way in which we regulate the questions of migration and immigration .

As I will argue later, a central key to the necessary ethical foundations lies in the concept of the person. The person-the term prevents us from considering human beings as commodities or isolated individual ciphers of identity comes into focus only when her or his history, beliefs, virtues, values, goals and actions are included in our judgements. If this is so, then interests connected to system imperatives having to do with money and power (or economics and the state) must be brought into relationship with lifeworld questions ${ }^{1}$. What will sustain healthy lifeworlds in a plural context of multiple lifeworlds potentially either in conflict with each other or synergistically engaged with each other? What will do so while allowing for a just economy and equitable structures of power'?

These questions can and should be answered practically, in relationship to existing financial, economic, bureaucratic and infrastructural constraints and possibilities. But they should also find an answer in adequate ethical foundations if decisions made on strategic grounds are to be sustainable over the long haul.

Some basis for establishing adequate norms is needed to guide the juridical and legislative policies that we should adopt. This normative dimension must counteract merely strategic or instrumental views on the problem of migrant populations. The normative dimension also draws us into the hermeneutic debate, that is, the debate about how we might construct useful (capable of being effected) and meaningful (producing a committed

12 The SADC currently consists of twelve member states in southern Africa.

13 Project Prospectus: The South African Migration Project. Institute for a Democratic Alternative in South Africa (Idasa), Cape Town, 1996/7. The project focuses on what it regards as the three main categories of migrants. viz. contracted mine workers. skilled immigrants ('brain drain' migrants), and undocumented migrants.

14 It is worth reminding the reader that 1 draw here on the familiar distinction from Habermas between lifeworld interests and system imperatives, whose relationship is regulated through law and similar procedures. 
consensus) criteria by which we may interpret what justice, equity and sustainability might mean in relation to the migrant populations of the SADC and elsewhere.

Let us take the issue of xenophobia as a test case. Xenophobic sentiment in the host country-particularly in South Africa where its regional strength in terms of much greater productive forces and infrastructural resources acts as a strong attractor - is part of the problem. The issue of xenophobia will allow us to begin to explore the hermeneutics of alienated otherness. This in turn, it is suggested, will offer us clues about the way in which we should develop useful and meaningful criteria for policy in the question of migrant populations. As we will see, this is only an entry point into the many levels of complexity attached to an analysis of alienated otherness, which can and should also proceed in other directions (such as its social-psychological dimensions, political-economic dimensions, personal-communal dimensions, and so on).

\section{III}

Following on the suggestion of a colleague, ${ }^{1}$ I shall begin with a notion that at first sight appears to confuse the issue and which would certainly be strange from a 'secular' point of view. This is the notion of demon possession, as it occurs in the biblical narratives of the New Testament. I think it offers an interesting, provocative angle to our investigation.

Demon possession should not be read merely as a narrative occasion for Jesus of Nazareth to be depicted as imbued with superior, even divine, power over evil. In fact, I am not interested in these narratives for the sake of any 'proof' of faith or of the meaning of faith, nor do I think that was in all likelihood the original narrative intention. Instead, my focus is on the signifying power of the notion of demon possession.

If one follows the narratives of demon possession, it seems to be a common feature that the one possessed by a demon no longer has control over a part of his or her life. An otherness has invaded the person, establishing a foothold in the psyche or soul, positing a presence which is both alien and different. The self, in this case, is not so much constructed as deconstructed by otherness. External behaviour patterns become evidence of this, so that people can say of a person why he or she is possessed. Criteria of behaviour, including tests for particular kind of behaviour, determine the fact or otherwise of possession 1 .

For the onlooker, the possession provides a second level of confrontation with an alien otherness, for the possessed person upon whom one looks is no longer the person one thought one knew. The strangeness in the one thought so familiar generates a particular kind of horror and fear. In pushing away the alien other-the demon-one necessarily pushes away the previously known self as well, for there was no way of distinguishing from the outside where the boundary between possession and self-possession ends.

Internal difference becomes external differentiation. Internal alienation becomes external rejection. The fact of possession cannot therefore be separated from its social context and location, and the healing of the possessed person likewise has to be located in a restoration of community, and with it, of the 'old' self. At this point, however, one might speculate that the experience of possession by an alien force or presence cannot be anything less than a socially located, communally derived disruption of normative patterns of action

15 With thanks to Juan Garces.

16 The recent film, The Crucible, based on the story of the witches of Salem, powerfully shows how this kind of drama plays itself out as members of the community testify for and against each other in terms of observed patterns of speech or behaviour. 
and behaviour. One only has to think of the role played by witchcraft in local African communities to see how strongly the communal and social element is present.

Demon possession may therefore be said to be both the result of a disruption in social and communal space as well as a cause of it. Similarly, demon possession might be seen as both a threat to the self and a threat to the community. Its alien character evokes fear in all concerned. Perhaps it is not surprising that this fear frequently drives in the direction of resolving the problem by eliminating or exorcising the person who embodies its cause, the one possessed.

Once it has reached this stage, it is very hard for the person possessed to regain a place in the community, for the nature of possession by a demon is that it is tricky, devious, outside of the operative norms of a community even as it destabilises those norms. As in an accusation of racism, once accused, it is very difficult to be found innocent again. The accusation has its own enduring historical effects. Alienation then becomes enduring too. Only a communally or religiously sanctioned ritual to exorcise the demon can break the cycle of alienation.

Perhaps it is in breaking such cycles, just as he broke the cycles of traditional law and logic around issues of the unclean, the prostitute, and the outcast, that the real significance of Jesus' healing of those possessed by demons lies. I will not venture to claim any authority as a biblical scholar in this matter. But I do want to take the signifying effect of the notion of demonisation into a wider discussion of possession and power.

Though demonisation is not the first step in the process of the alienation of the other, perhaps only arising when the challenge posed by an unknown and threatening is particularly strong, there remain earlier forms of alienation - antecedents, relatives of the demon-which might similarly lead to a defence of the community and an expulsion of the other.

Where this takes on proportions significant enough to produce a feeling that the lifeworld of the community itself is under threat, the discourse of demonisation is likely to arise again. One of the most obvious examples in our time may be found in the ideology of the Nazi Reich, in which a critical mass of the populace found ready solace for its fears in the idea that gypsies, the mentally ill and Jews represented the alien presence in society, the demons, who must be exorcised and eliminated. An apparatus had to emerge, insidious and pervasive, extending into the inner reaches of families and friendships, to identify the demons and to remove them from the community.

Certainly, economic crisis and political shame (arising from the results of World War I and the subsequent Versailles Treaty), coupled to a powerful symbolic regeneration of supposedly archetypal cultural identities in the Aryan ideal, allowed for demonisation to take hold. But that is only the last step. The question we face is whether the first steps on the way to exorcism and elimination can be addressed, and the pathologies lurking behind them healed in a way that allows to the other the space and place that one asks for oneself.

\section{IV}

Xenophobia is a symptom. To be sure, its causes are neither simple nor single. Any detailed analysis of the phenomenon would necessarily have to take into account particular constellations of space, place, body and power. But one set of issues which arise frequently in the context of xenophobic sentiments, either as a legitimising discourse or as a genuine feeling, has to do with notions of patriotism and nationalism. At a level below that of the national state in a country such as South Africa, similar concepts would function to define 
in-groups and out-groups, whether conceived as clans, kingdoms, tribes or other ethnic units of custom, behaviour and culture.

It is the issue of patriotism in relation to the concept of nationalism that I wish to draw into the discussion, utilising an important set of distinctions made by Jean Bethke Elshtain ${ }^{1}$. In my view, this will take us some important steps further in considering the criteria which should guide our understandings of alienated otherness in the context of the problem of migrant populations.

Elshtain begins by noting that for a long time the idea of patriotism has received bad press - as cynical discourse and the last refuge of scoundrels - among sceptics, liberals and others. She proposes to reclaim the notion, however, in order to open up space for renewed political action, and because she regards it to be simplistic and arrogant 'to dismiss the issues involved as an easy matter of reactionary atavism, on the one hand, and rational progressivism, on the other.'

In pursuit of her goal to she intends to distinguish between patriotism and nationalism. The two are usually associated with each other under the modern nation state. In her view, this association is the real problem. In fact, she argues, patriotism stands against nationalism and not with it. On what does she base this distinction?

In the first place, and quite importantly, patriotism for Elshtain is 'thick with life.' For a proper understanding of patriotism 'one must turn to symbols, examples, stories of lived lives.' From within this thick life, patriotism 'creates a political space of limits' because a specific cultural and political homeland 'is a counter-universalist form.' A true patriot is therefore respectful of limits and acknowledges a pluralist world. The notion of the true patriot therefore 'invites, as one possibility, respect for the construction of identities different from her own, for others have need of their particular containers for beings as well.'

This is not at all the logic or the method of nationalism. On the contrary, Elshtain declares, the nationalist challenges limits 'as possible means to enhance the power of his own state in relation to all others.' Using a particular interesting and fruitful metaphor for the question of an appropriate hermeneutics of alienated otherness, she suggests that nationalism 'frames political space from the top down, not, as patriotism does, from the bottom up.' In this framing, state sovereignty is the key, the highest good. Its final appeal is force.

The distinction between nationalism and patriotism may also be discerned in another direction, that of the essential political dynamic underlying each. Elshtain's argument is that nationalism requires people to 'be available as raw material for mobilisation' (the military being the prime expression of this dynamic), whereas patriotism is constituted through civic participation. These are two qualitatively different experiences.

The key for our purposes in this essay is her contention that nationalist concepts of statehood 'turn on the presence of enemies within and without.' The contradiction to nationalism posed by patriotism is best captured, in her view, by the life stories of people like Martin Luther King and Dietrich Bonhoeffer. Bonhoeffer, for example, she sees (correctly, I believe) as a German patriot committed to an international oikumene who understood the costs of patriotism in the face of rampant nationalism.

17 Jean Bethke Elshtain, 'On Patriotism,' in Power Trips and Other Journeys: Essays in Feminism as Civic Discourse, Madison: University of Wisconsin Press, 1990, pp. 163-177.

18 Ibid., p. 164. 
Here the self confronts the demon within, through its constitution by the other, and refuses to accede to its desire to possess all the right to determine - or remove-the existence of the other. It turns against the nationalist impulse, to rescue the basis not only of its own authentic existence and identity, but of the possibility of a healthy rather than a destructive human existence with and for others. This is not, in the case of Elshtain's understanding of patriotism, 'merely' a theological claim (as in the case of Bonhoeffer or King); it is also a social claim and a political one.

Elshtain's analysis of King in this respect revolves around his speech about the Vietnam war and US involvement in it. His criticism of the war arises precisely because its effect is to glorify nationalism in such a way as to defeat the genuine patriotism that might provide a unifying bond in a plural society for the populace of the USA. The logic of the Vietnam War, in this light, is one rooted in the construction of civil life in the USA around a notion of homogeneity-it is a logic which demonises the other in her specificity and difference. This demonisation is carried out in the name of an abstract, grandiose image of unitary power (carried in terms such as 'the national interest') by which difference is ironically isolated and condemned as 'unpatriotic.' Thus, it was sufficient to call someone 'communist' to begin the process of witch-hunting, exorcism and dispossession.

But Elshtain does not end there. Drawing on the work of Rousseau, whom she lauds for his defence of 'the freedom and autonomy of bodies-politics,' she notes that there are various patriotism's between which one must choose. In the case of Rousseau, he constructs a picture of the patriot which bears the marks of all that is virtuous in the eyes of Elshtain, except at the point where he links it to the image of the soldier. The soldier is not, here, in the first instance, the signifier of war, but of masculinity, of the vigour needed for public life, of a strong citizenship. The gender construction of the concept of patriotism and civic life is all too obvious.

If past wars did not, then modern wars reveal how spurious such a construction is. There is nothing heroic about war in our time, if ever the notion of honour was adequately defined in this context above all. Thus Elshtain finally comes to the notion of 'the chastened patriot,' the one stripped of the excesses of nationalism. The chastened patriot keeps alive the dangers of nationalism's, large and small, through 'the distancing voice of ironic remembrance and rueful recognition.' The chastened patriot works to weaken both the principle of nationalism and its secularisation of the state. "The chastened patriot is committed and detached; enough apart that he or she can be reflective about civic ties and loyalties. .... Chastened patriots cherish many loyalties and speak in many voices: a reclaimed patriotic choir is polyphonic.' The chastened patriot has no illusions as she or he works to break cycles of fear and vengeance.

In Elshtain's analysis of patriotism we uncover one of the hermeneutic keys to unlocking patterns of alienated otherness. The polyphony of otherness is cherished: The chastened patriot, seeking to be constituted through civic participation and framing space from the bottom up, hurries to protect the virtues of both polyphony and of the other.

\section{V}

The final step in this limited attempt to unpack some of the dimensions of alienated otherness leads us to Paul Ricoeur's philosophical ethics, as found in his seminal work on 
Oneself as Another. ${ }^{19}$ His ethics, unlike the increasingly dominant model of rational choice theory, depends upon anthropology-upon a reviewed view of the human person.

In the context of the claim, following Strawson, that the person is a 'basic particular' (because we cannot go behind the concept of the person without presupposing it in any argument that might try to derive it from something else), Ricoeur works out his now wellknown distinction between sameness and selfhood. Sameness (idem-identity) binds me spatio-temporally through 'ascription' implying continuity and species or group identity. Selfhood (ipse-identity) frees me from ascription, implying uniqueness and personal identity. But, Ricoeur notes ${ }^{20}$, "there is no self alone at the start; the ascription to others is just as primitive as the ascription to oneself.' Thus, while our language of the first and second person singular ('I,' 'you') expresses a reflexive relationship - a self designation - the notion of a person as a basic particular demands that we recognise that our third person language refers to a third party who is not one of our interlocutors. There is an identifying reference which is public here. Its importance lies in the objective designation of what it means to be a person, and not merely in the subjective domain. Yet the third party is not wholly other, outside of our spatio-temporal realm. As such the third party lays a claim on our selfhood as well. What is this claim? Condensing Ricoeur's argument dramatically, it turns out to be a claim of a double kind.

First, it is with others we live and by which we live, as persons. The self is constructed not just by the other, but in relation to the other. This claim, because it is anthropological and simultaneously ontological, refers to the nature of human being and becoming ${ }^{21}$. Second, this anthropology leads to an ethical claim which Ricoeur calls the 'ethical intention.' The ethical intention, to repeat what we have just said, aims 'at the 'good life' with and for others, in just institutions. 22 Selfhood and otherness are joined and enjoined in this double claim, in such a way as to ground personhood, both subjectively and objectively.

I have paid no attention in this brief excursus to the first 'basic particular' of individual human beings as defined by Strawson, namely, the body. Ricoeur takes 'bodies' into account as well, and so should anyone reading my text if it is not to be misinterpreted to refer only to consciousness, mental states or psychological realities. The person both possesses and is a body. There can be no mind/body dualism here, nor can one abstract persons from what happens to their bodies.

With that caution in mind, we may ask what the payoff is of this view on ethics framed within the concept of the person? To respond to that question, it may be useful to see how Ricoeur responds to one of the other great alternative anthropologies of our time in the writings of Levinas.

Levinas, we may recall, developed the image of 'the face' as one of the defining metaphors of the ethical nature of the encounter with the other. 'The face' of the other, be it filled with pain, anger, hatred or love, confronts us as entirely other, and demands from us a response. This demand, a charge addressed to us, is the characteristic modality of the

19 Paul Ricoeur, Oneself as Another, University of Chicago Press, 1992.

20 Ibid., p.38.

21 Ricoeur does not resort to an outdated metaphysics in asserting ontological foundations for the notion of the self-in-relation-to-the-other, but traces this claim through an understanding of life is a narrative unity, one which 'must be seen as an unstable mixture of fabulation and actual experience.' Ibid., p. 162. For my purposes, however, the ontological issue is secondary. Rather, I am interested in how this impacts on Ricoeur's philosophical ethics.

22 Ibid., p. 167 [my emphasis]. 
encounter with the face of the other. Note here that there is a consequent loss in the notion of being with the other, of being constituted by the other in any other way than externally.

It is at this point that Ricoeur criticises Levinas, suggesting that:

this face is that of a master of justice, of a master who instructs and who does so only in the ethical mode: this face forbids murder and commands justice. .... To be sure, the self is 'summoned to responsibility' by the other. But as the initiative of the injunction comes from the other, it is in the accusative mode alone that the self is enjoined. ${ }^{23}$

It is not that Levinas is wrong, but that his vision of the other is too stark, too limited. 'To [this] alternative,' says Ricoeur, 'I shall stubbornly oppose the original and originary character of what appears to me to constitute the third modality of otherness, namely being enjoined as the structure of selfhood. ${ }^{, 24}$ What is the nature of this 'enjoining'? It is founded on the attestation of the self, including the self of the other. This alone allows for and explains our capacity to hear the other as other (and not merely as an extension of our self, or perhaps, as the voice of our superego), to be affected by the other. The aporia of the other lies in this tension between the 'trace' (Levinas) and the 'epiphany' (Ricoeur) of the other.

Now, we may ask, what is the nature of this 'epiphany'? Here Ricoeur makes a decisive move to an anthropology that will sound strange to those brought up on the Cartesian mentalist model of the ego or the Nietzschian celebration of the will to power or, indeed, the Marxian notion of material value. The primordial epiphany, the other side of the injunction of the other, is suffering. What Ricoeur means here, however, is more than pain or grief, but rather 'the reduction, even the destruction of the capacity for acting, of being-able-to-act, experienced as a violation of self-integrity. ${ }^{25}$ Perhaps a more concise phrasing, from the final pages of Ricoeur's essay on the self and the other, is that 'With the decrease of the power of acting, experienced as a decrease of the effort of existing, the reign of suffering, properly speaking, commences. ${ }^{, 26}$

Faced with this kind of other, it immediately becomes clear why Ricoeur regards 'the sense of justice to follow directly from the notion of the other in the aim of 'living well' (which we may take to be his short-hand formulation of the goal of ethics). It does not seem very difficult to see the implications of such a position for the question of foreign migration or immigration, or for the question, more generally, of alienated otherness.

The foreigner is the third party, the objective other who is joined to us through just institutions (otherwise we are both ultimately destroyed in the results of injustice working itself out on us). The foreigner in our midst requires that we ascribe to her or him the same kind of basic particularity that we claim for ourselves, including our identity and our uniqueness. The foreigner, therefore, has claim to existence, expressed as the power to ad, and denied in proportion to her or his suffering. Similarly, our living well, in the interconnection between us and the foreigner in a shared spatio-temporal realm, depends in the long run upon she or he living well.

Equally important, alongside these ethical imperatives of the ascription of otherness to the foreign person, is the constitution of our selfhood and our power to designate our selves reflexively in relation to the other. What this might mean is that we are diminished to the 
extent that we diminish the other, disrespect her or his selfhood, including her or his selfutterance. This self-utterance requires that we hear it, grasp its disclosive power in the epiphany of the self which can be celebrated and shared. In other words, the foreign other is, more than a threat, also an enrichment, at least potentially. The enrichment may be quite literal (economic benefits, for example) and it may be equally cultural, religious or philosophical. The capacity of a society to draw upon these riches will depend, quite obviously, on its capacity to deal with the foreigner justly, in terms of the need of all to live well with and for each other.

Notwithstanding these powerful foundations for a practice which is ethically sound and anthropologically profound, we must recognise that the patterns of encounter and negotiation, acceptance and rejection, are complex and the demands for living well in just institutions not easy to balance where competing interests are at stake. A final insight from Ricoeur, about the tragic nature of the narrative unity of life, helps us to understand how this reality might enter into our consideration of the alienated other.

We do not and should not discount tragedy-the failure to meet the ethical imperatives outlined above and the consequent damage done to persons. Whatever the causes of tragedy (which we must also take into account, of course, if we are not to respond naively), tragedy itself is not necessarily fateful, something of which we are merely victims. The ethical foundations Ricoeur provides point in another direction, one which we might regard as characteristic too of the deepest ethical insights of the great religions of the world into its pain and failure. They point in the direction of an ethic of risk and a life of conviction. In Ricoeur's words ${ }^{27}$,

... tragedy, after having disoriented the gaze, condemns the person of praxis to reorient action, at his or her own risk, in the sense of a practical wisdom in situation that best responds to tragic wisdom. This response ... makes conviction the haven beyond catharsis. ... This transition from catharsis to conviction consists essentially in a meditation on the inevitable place of conflict in moral life.

The kinds of policies required to deal with the foreigner will always be followed by the ambiguities described by tragic wisdom, and in Ricoeur's view we cannot escape the plurality of ethics inherent in the narrative unity of life. Nor, for that matter, can we escape the fact that the ends of 'good' government are similarly plural, open not only to debate and alternative positions, but subject to the irreducible multiplicity of lifeworlds, values and goals which constitute a society in itself, and in relation to other societies. The crucial realisation here, one familiar to all good people who must govern (and often not understood or wilful misunderstood by those who stand outside of the demand to govern), is that 'The irreducible plurality of the ends of 'good' government implies that the historical realisation of one set of values can be obtained only at the expense of another set; in short, this implies that one cannot serve all values at once. ${ }^{28}$

It remains only to quote Ricoeur once more to conclude the argument of this section, an argument essentially designed to establish the kind of criteria for assessing how to deal with the foreigner (and the alienated other, in general) ${ }^{29}$ : 
... on the one hand, one must maintain the universal claim attached to a few values where the universal and the historical intersect, and on the other hand, one must submit this claim to discussion, not on a formal level, but on the level of the convictions incorporated in concrete forms of life. Nothing can result from this discussion unless every party recognises that other potential universals are contained in so-called exotic cultures. The path of eventual consensus can emerge only from mutual recognition on the level of acceptability, that is, by admitting a possible truth, admitting proposals of meaning that are at first foreign to us.

I would submit that this conclusion drives us to re-imagine our relationship to the foreigner, and to imaginatively create the kinds of just institutions which would regulate this relationship to the end that all live well together. Of course this is not a simple task, but it is an important one-not only because it is enjoined of us ethically, but also because it is a socially wise one.

\section{VI}

As indicated earlier, I have not yet considered that other basic particular of the human individual, the body. In conclusion, let me return to another work of Jean Bethke Elshtain, this time to quote her reference to Foucault in the context of an analysis of 'bodies social and political. ${ }^{30}$ Foucault, she notes, argues that the body is the inscribed surface of events, and that the task of genealogy is 'to expose a body totally imprinted by history and the process of history's destruction of the body. ${ }^{31}$ It is 'sensibility' to the experience of the body, whether in predicament or in celebration, that Elshtain considers most vital. This sensibility takes us out of and beyond merely strategic and instrumental rationality, indeed, beyond any rationality located primarily in the mind, to resources of imagination capable of linking with what Elshtain calls our 'primordial social inclination' of pity or compassion, without which 'life would be wholly brutal. ${ }^{32}$

Moments of 'sharp pity' and 'ecstatic reverie' are for Elshtain sources of enthusiasm for truth and the well springs of sensibility. As she puts it, 'for most of us most of the time scientific discourse is irrelevant. We have more important resources at our command because we can both act and imagine.' Our acting and imagining are not abstract qualities, but embodied in history and embodied by a particular history. It is this which gives them force, pertinence and persistence.

One might put it sociologically: Our lifeworld interests and discourses are enriched by feeling, acting and imagining in ways which cannot be grasped by instrumental or strategic rationality, and these ways provide us with the backbone whereby we are able to defend (negatively) and extend (positively) the significance and value of our lifeworld through commitment to its integrity and its communion with other lifeworlds in the search for a whole and healthy society.

One might rephrase this insight philosophically: Referring to the work and witness of Jane Addams, a leading progressive and social and political theorist of American society in the early part of this century, Elshtain notes that 'she generalises universal imperatives from thickly described particular dilemmas and events' where the difference of the other is taken

30 Jean Bethke Elshtain, 'Rousseau Redux: Bodies Social and Political,' in Meditations on Modern Political Thought: Masculine Feminine Themes from Luther to Arendt, New York: Praeger, 1986.

31 Ibid., p. $43 . \mathrm{s}$

32 Ibid., p. 45. 
into one's own self-understanding, this in order to be able to understand any feature of social life. ${ }^{33}$ The world in which Jane Addams wrote thus was one not dissimilar to ours now-dominated by the rise of the market, the transformation of the primary relations of family and clan, of small town and village, the influx of thousands of immigrants into every centre, the spread of crime, unemployment, poverty, illness, unsanitary conditions and prostitution. In this context Addams spoke particularly to the plight and the possibility of women, arguing that one must 'resist grand claims couched in universal abstractions and bring matters down to earth.'

One might put it in terms of aesthetics: 'Here,' says McLean, ${ }^{34}$ 'the imagination, in working toward an integrating unity, is not confined by the necessitating structures of categories and concepts, but ranges freely over the full sweep of reality in all its dimensions ....' This is the productive rather than the merely reproductive work of the human person, through which one finds the 'ability to assess the overall situation' and 'express it in a manner which rings true,' thereby being able to 'evoke appropriate and varied responses.' One turns in this mode to a form of analysis which is as vital as it is often underplayed, missed or ignored. This is an analysis of our culture, our politics, our economics in terms of the way it manifests beauty or ugliness, actual or potential, in its concrete realisation of social relations. The aesthetic categories of beauty and ugliness, however contested these terms, touch on sensitivities that help us identify what. is good practice and what. bad because they drive us to take into account greater dimensions of reality than those fossilised in existing boundaries between the self and the world, the self and the other. They also allow us to link imagination to possibility rather than mere actuality in overcoming the ugly by creative responses to the lure of the beautiful.

One might also put it theologically: That spirit which engages us in inspiring us to act with commitment to the other on the basis of love for God and love of the self others us a way of being and becoming which transcends the limits of alienation and insularity in order to insist on the ethical touchstone of the worth of the particular, embodied person, however 'alien,' for the sake of all.

It would not be appropriate, however, to end on a note of theological conviction or the triumph of faith, for such a note too readily translates in the mind of most people into a superficial grasp of reality. Reality is not only about conviction and hope, important as both are if we are not to become fatalistic victims of the machinations of interests that have no transcendent human ethic at their heart. Reality is also about demons and demon possession and the victory of alienated otherness over us.

Thus Elshtain reminds us in her reading of Jane Addams that her optimistic reformism and idealist hopes of the impact of social movements, associations and organisations on the possibilities of constructing a benign state imbued with the virtues she prized were broken in half by World War I. A progressive society is not a necessary, perhaps even an unlikely, outcome of the penultimate hopes of ordinary people, especially if its anthropological foundations rest upon the notion of the individual ego. War, for her, demonstrated 'an errant capitulation to murder, an embrace of the state as an engine of death. ${ }^{, 35}$

In war, two false criteria of the common good emerge where all can see them plainly. The one is found in the discourse of heroism, in what is historically seen primarily as

33 Ibid., p. 79, in an essay on 'Self/Other, Citizen/State: GWF Hegel and Jane Addams.'

34 McLean, op. cit., p. 31

35 Elshtain, 'Self/Other, Citizen/State,' p. 81. 
'celebrations of selfless male action,' but which stand essentially against both the self and the other in 'a centuries-old trail of tears.' The second false criterion may be found in the way in which the 'generalised other', the state at war, subverts particular selves. Wars require a particular kind of solidarity, but its solidarity is one which attacks a broader basis of human being. Here Addams sees 'civic tragedy, the reaffirmation of force, and the crushing of lives and hopes.'

In this light, the pride and identity of a nation, of an ethnic group, or of any similar social unit, may produce precisely that which an ethic against alienated otherness resists. We would be well advised to consider the 'aliens' in our midst in terms of overcoming practices and structures which produce alienated otherness, for wherever we allow the opposite, no matter in how minor a degree, we breed the conditions for the rupture of the body politic itself.

It is with that ambiguity in mind, and the warning hint from Elshtain's interpretation of Addams that this includes a gendered construction of reality which still needs to be deconstructed, that we must view our encounters of the first kind. Perhaps, with that thought in mind, I might then describe encounters of the fifth kind as those that have failed at the earlier point: Their product is alienated otherness, their logic is not discourse but violence. The logic of the language of the 'kafir' - in its past and in its analogous forms in the present - is the logic of conquest, colonisation and war. 